\title{
The Roles of Religious Education to Peace, Security and Sustainable Development in Nigeria
}

\author{
${ }^{1}$ Dr. Sulaiman Kamal-Deen Olawale, ${ }^{2}$ Dr. Mrs Ojo Margaret Yemisi \\ ${ }^{1,2}$ Department of Religious Studies, Faculty of Arts, Ekiti State University, Ado-Ekiti, Nigeria
}

\begin{abstract}
Divorcing religion and moral educations is an impossible task because of their long-standing historical antecedents. Religious education will certainly form a backbone to moral education. To enhance a moral society, there is the need for value and civic education in Nigeria. This paper however, intends to look at religious concept of peace and security. It also examines the need for peace and security in Nigeria. Likewise, the paper highlights the role of religious education to peace, security and sustainable development in Nigeria. In terms of methodology, the data used include both primary and secondary sources. The paper revealed that, the prominence of religious education will instill values and high morals on the citizenry to bring about expected sustainable development. The principal religions recognized in Nigeria are Islam Christianity and African Traditional Religion. Each of these has deep roles to play in enhancing peace, security and sustainable development. It concluded that, the role of religious education to peace, security and sustainable development in Nigeria can not be over emphasized. The Federal Government of Nigeria owes it a duty to re-introduce the teaching and learning of religious education in Nigerian schools and make it compulsory for all students. However, religious bigotry should be stamped out and proper tenets of religions should be taught and practiced. The paper therefore recommended that, religion as a subject should be made compulsory for students at all levels of the educational system right from the primary up to the tertiary level. Today it is an elective subject at the secondary schools level and is not made compulsory even for undergraduates. This idea should be reviewed, so that all students in all institutions of learning irrespective of the level and choice of career should be compelled to offer religious studies. Effective teaching of religious studies and uplifting of moral and spiritual values by the religious leaders will go a long way to bring about peace and security in Nigeria. The Bible and the Holy Qur'an which are the basis of religious studies emphasized all these communal expectations. It shows that Christianity and Islam are religions of harmony, unity, security and peace which Nigeria would need for its sustainable development. These principles must be taught the more for the betterment of the youths in Nigeria.
\end{abstract}

\section{Introduction}

Over the years, Nigeria had been tagged "security risk nation" to which many international communities have warned their nationals not to live or even travel to Nigeria. Taking cursory look at the happenings in and around Nigeria, one may be tempted to agree with these international communities that their fears justified. This is because Nigeria has been experiencing a number of crises, social-vices and lack of cordial relationship among her citizens since independence. There have been constant hostilities among the inhabitants of one village, town, city and the other; one state and another or inhabitants of the same town or the same state based on tribal, religions or ideological differences. Also violent conflict has developed a pervasive phenomenon in most Nigerian communities. The various political party crises that finally led to the 1967-1970 civil war have had devastating, effects on unity and peaceful co-existence in Nigeria. Further more, the intensity frequency and rapid spread of crises in recent times is an issue of intense public concern. In most states of the federation, one hears stories of violent conflict involving individuals or groups. For instances, Ife-Modakeke crisis in Osun State, Jukun-Tiv war in Taraba-State, Odi Massacre in Bayelsa State, Urhobo, Izon, Itsekiri crisis in Warri, Jimeta conflict, Rigasa up-rising in Kaduna State in !980, Muslim-Christian clash in Jos 2001, 2005,2010, (Egwu, 2001 and Alanamu, 2004), Boko Haram uprising in Bauchi in 1980, 2010, 2011, Yobe, Katsina (Abdul Rafiu, 2001, Adeniji and Nmeriben, 2009), the 1980's Maitasine uprising in Kano, the Kaduna upheavals of 2000, 2011, others include Shagamu Hausa/Yoruba crisis (2000), the Ogoni/Elepolo crisis 2003, the current Boko Haram mayhem in North Eastern part of Nigeria, among many others.

Worst still is everyday armed robbery infliction on both individuals and financial institutions. The Nigerian police, an institution charged with the responsibility of protecting lives and properties have failed in their duties, many of them do rent out arms and ammunitions to armed robbers. Some of them even engage in armed robbery and lorry loads of arms and ammunitions can be transported from Lagos to Kano or from Maiduguri to Port-Harcourt as long as the lorry drivers are ready to part with twenty naira bribe at every police check point or road block.

In these conflicts, people are displaced, properties are destroyed and lives are lost. For instance, the Booko Haram disturbance in northern Nigeria claimed at least 600 persons with over 3,000 residents already 
displaced (Orulu, 2009). In Delta State, the Gbaramatu Kingdom Genocide witnessed several losses of innocent and helpless children, women and the aged were lost, property belonging to individuals and group worth billions of Naira were destroyed by the joint task force. This resulted in large scale physical displacement and forced relocation of individuals, families and other (Ogege, 2009). Therefore, communities in Nigeria are in a crisis situation devoid of peace and as such, there is need for quick solution before it degenerates in to a full blown civil war.

Other negative impact of violent conflict on sustainable Development in Nigeria is the destruction of lives, properties and critical infrastructure. For instance, the Nigerian civil war left Igbo land devastated, with vital infrastructures lacking and people' final base eroded. It is in the light of the above situation that peace building initiatives and religious Education have to must be integrated into the process of sustainable development in Nigeria. The challenge before Nigeria is to develop the needed institutional capacity that will sustain development, transformation and reconciliation through social enlightment, peace and Religious Education.

\section{Definition of Terms}

Religion, unlike other disciplines like Music, Geography, History, Mathematics, Chemistry and a host of others, has no universally acceptable and satisfactory definition. Therefore, there is no single universal accept definition of religion as a concept of scholars. Religion is looked at from different perspectives based on the angle which one understands it. However, according to Webster's Dictionary of English Language, Religion refers to man's expression of his acknowledgement of the divine or a system of belief and practices relating to the sacred and uniting its adherents in communities. This shows that religion focuses on what is ultimate or absolute and taught of worship. Therefore, relationships between the transcendent and men demands total submission and an absolute obedience. According to James (2007) an important dimension to the definition of religion, which is essential for the search for peace, is the often forgotten fact that religious relationship is in fact two dimensional. It is not only vertical but also horizontal; it does not only refer to the relationship between man and God, but also the relationship between man and the society. Therefore Religious education can be seen as a process through which a person learns something which his society believed is related to God. According to Lawal (2003) Religious education can also be described as those processes designed to induct each new generation into the attitudes, beliefs as well as the practices of a religions or faith in order to promote the religion and at the same time provide for the individual a unifying center for his life.

\section{Peace.}

According to Oxford Advance Learners Dictionary, peace is a situation or a period of time in which there is no war or violence in a country or an area, state of being calm, of quietude and living in friendship with somebody. Also, peace as define by the Concise Oxford. Dictionary of Current English (1998) is peace in three perspectives mainly quiet/ tranquility, mental calmness serenity and freedom from or the cessation of war. The World Book Encyclopedia (1996) says, peace is the state of being calm, quite and freedom from disturbance. Peace has also defined as the "state of freedom from war or freedom from civil disorder (Matthew and Ladan, 2004). Hence, peace is security because when one is free without fear, when there is peace, people then will have freedom to develop their social lives. It is the breach of peace that causes civil disorder, rioting and other forms of disharmony or instability. Any society that is not living in peace must live in war or conflict, whereas peace connotes calmness, rest of mind and freedom without arguing.

\section{Security}

The word 'Security' can be viewed from various angles depending on the situation with reference to specific cases. The reason being that by nature the concept is imprecise. For instance, Hornsby (1994) defines it as "safety from danger or anxiety in another word, security refers to something valuable which Ambi, (2005) defined as the quality or condition of being freed from exposure to danger, protection, feeling or assurance of safety, freedom from anxiety or doubt. Security is invulnerability and defensive capacity. The issue of security could result from injustice, where people result to violence because they feel they do not get justice. According to Chambers Dictionary (1993), security is the state or feeling of being secured, protected from espionages, theft, attacks etc. The New Encyclopedia Britannica described security as the protection of persons and property against a range of hazards, including crime, fire and attendant risks, such as explosion, accidents, disasters, sabotage, subversion, civil disturbances, bombings (both actual and threatened) and in some systems, attacks by external enemies.

From the various definitions of security stated above, one can conclude that security is not just military protection or repulsion of external aggression and internal upheaval or any act that could threaten the peace and security of a nation. It also includes environmental stability, economic well-being, demographic issues, good governance etc. 


\section{Sustainable Development}

The concept of Sustainable Development is related to the need for the institutionalization of best business practices by companies, corporations and sundry business concerns as well as governments in the processes of production, distribution and consumption, vis-à-vis their economic, socio-political and environmental spheres of activity. According to World Development Report (2003), Sustainability is an evolving framework. Societies will continue to transform over time and since significant social stress and crisis is likely to lead to a breakdown in the development and preservation of all assets, inter-generational well-being is bound to be jeopardized. Sustainable Development means improving the living condition of the people by integrating social Development, economic development and environmental conservation and protection (Olayode, 2006). Essentially, it is about the welfare of all. Hence, sustainable Development is also defined as a development that meets the need of the present without compromising the ability of the future generations to meet their needs (WCED, cf, Olayode, 2006). It also means capacity to continue into the future (Barbier 1959, David 1986, cited in Olayode, 2006). It is to be noted that, this concept applies not only to environmental issues, but also incorporated into economic and social issues.

\section{The Role of Religious Education}

No religion preaches violence and conflict or militancy. Every religion advocates and preaches peace and peaceful co-existence of all citizens. In Christianity Jesus Christ is known and referred to as the prince of peace. He taught, commanded and demonstrated the significance of peace and "his is name will be called wonderful, counselor, mighty God, everlasting father, prince of peace" (Isaiah 9: 6-7). "Salt is good; but if the salt has lost its saltiness, how will you season it? Have salt in yourselves and be at peace with one another (Mark 9: 50). Furthermore, the Bible says: "Let us then pursue what makes for peace and for mutual up building". (Romans 14:19) Throughout Jesus' earthly ministry, he demonstrated his to love and maintained peace with all men. Despite stiff opposition from the Pharisees and religious leaders, he never said any rude or insulting word to them. Even when he was arrested and Peter had to draw his sword to cut off the ear of the slave of the High Priest, Jesus cautioned Peter and replaced the ear. He was led to be crucified like a lamb that is dumb, for he said no word, to show the level to which he pursued peace.

Islam also calls for the quest for peace, tolerance and kindness which is a state of physical, mental, spiritual and social harmony. Other virtues of Islam are that Muslims were urged to imbibe the spirit of kindness and forgiveness. (Q3:124) and further enjoined to live in harmony and peace with fellow human beings, Repel evil with that which is better and show perseverance with patience (Q 3: 200).

These values and virtues were practically demonstrated by the Holy Prophet Muhammad (S.A.W). He used non-violent methods to resist those who persecuted him. He never resorted to violence or force unless as defensive mechanism. Peace making, negotiation and dialogue are considered more effective than aggression and violent confrontations. For instance, the virtue of tolerance and forgiveness as demonstrated by the Prophet Muhammad (S.A.W) can be seen vividly when there was famine in Mecca and he helped them despite the fact that they had driven him out of his home. Similarly, after the conquest of Mecca, the people of Mecca expected Prophet Muhammad (SAW) either executes to them in retaliation, take them as slaves or at least confiscate their properties and belongings. They were extremely worried and wondered what declaration he was going to make at his historic occasion. However, he began his address by saying to the pagans of Mecca: "Today there will be no blame on you for anything and no one will harm you in anyway"

Such example of rear nobility and humanness is rear in human history. These are the type of behaviour expected from Muslims, as exemplified by the Prophet of Islam. In fact there are several examples of this nature in the life of the Holy prophet.

Having examined the major religions, it could be seen that peace is of paramount importance to any meaningful development and religious teachings can provide the needed peaceful atmosphere if used in the right perspective.

\section{Recommendations}

In the light of the above discourse, the following recommendations are hereby proffered to promote peace, security and sustainable Development through religious education.

The teachers of religious education at all levels of Nigerian educational system should be consistent in promoting morality and ethical values while imparting religious knowledge on students.

The students should be encouraged to demonstrate such moral values in their day to day dealings or affairs with other fellow men.

Religious leaders, in and outside government circles, should serve as good ambassadors of Religions by demonstrating ethical values of kindness, tolerance, forgiveness, and consideration for others in all circumstances. 
All obstacles that may hinder practical implementation of the moral values taught through religious Education should be removed.

It is pertinent now for a conscious attempt to re-read re-examine and re-interprets the Holy Scriptures, and religions doctrines to make them more meaningful toward establishing an egalitarian society, where all people will be at peace with each other.

The Religious Teachers should preach and teach the word of God in its true meaning to the students and not to mislead them through negative indoctrinations and zealotry.

Religious students themselves should not use their own cultural and historical background to condemn and seek to destroy other religions arising from a different cultural and historical setting.

Nigerians should be re-oriented to see each other as brethren no matter their religious differences.

Proper positive religious education and orientation is to be given, so that ignorance can be wiped out.

At home, parents and siblings are to encourage folk stories that stressed tolerance, endurance, justice and peaceful co-existence among mankind.

At school, comparative religion can be thought to enable students to compare and contrast with emphasis laid on areas of agreement, tolerance and security of lives and properties. This will help to eradicate ignorance and engender mutual understanding.

Respect and loyalty that members have for their religion should be transferred to that of the nation. This helps them to fit into the wider society.

Dialogue between different religious groups can be arranged. This will create a common forum for exchange of idea and understanding, consensus building and cooperation through citizenry.

A Professional body for the study of religion can be set up. They should eradicate ignorance through conferences and seminars, where issues that are threat to peace and security should be addressed.

Religious institutions are to be encouraged against the deliberate and mutual use of arms in resolving conflicts and disputes arising from the question of inter-religious relations.

Equal rights and freedom of all citizen of the Nigeria pluralistic society should guarantee. This helps people to express themselves, ask questions and demonstrate their potentialities.

The above recommendations will surely help to preserve and maintain peace, security and sustainable development in the large society, more so that majority of the populace belongs to either of the two major religions in Nigeria (Christianity and Islam).

\section{Conclusion}

The Roles of Religious Education to Peace, Security and Sustainable Development in Nigeria can not be over emphasized. However, much as we are all eager to see a virile society where peace, security and Sustainable development reigns, this aspiration can only be realized true if we all make conscious efforts to see it happen. The Federal Government of Nigeria owes it as a duty to re-introduce the teaching and learning of religious education in Nigerian Schools and make it compulsory for all students. Also, our political, social and religious leaders must make concrete efforts to see that peace reigns supreme throughout the country. However, religious bigotry should be stamped out and proper tenets of religious teachings are taught and practiced.

As previously mentioned, when religion is rightly handled could be the solution to the incessant violence, confrontation and conflicts in Nigeria. What is needed is an understanding of when and how to gingerly handles religion as a new bride to serve a positive purpose in the society.

\section{References}

[1] Abdul Rafiu, L (2009): Rage of the Puritan; Tell, no. 32, Aug, Pp, 10-32

[2] Adebimpe, A and Adeleke, G.O (2008) In Journal of Social Psychology Practice, International Perspective, Vol,1. No.1\&2

[3] Adeniji et al (eds) National Association for the Promotion of Studies in Religious, Education, Languages and General-Studies

[4] Alanamu, S.A (2004) "Reflections on Religious Violence in Nigeria 199-2003" In Alanamu, S.A (ed) Issues in Political Violence in Nigeria, Ilorin, University Press

[5] Ambi, P.M (2005) "Resources Conflict and Security in Africa, An Over-view of Angola" Journal for Promotion of Studies in Religion, Educational and Language, Vol, 4, No1, P. 69

[6] Chalmers, D.M (2003): Encyclopedia Americana. Sustainable Development

[7] Egwu, S (2001): Ethic and Religious Violence in Nigeria. Jos, St Stephen Book Inc

[8] Hornby, A.S (1974): Oxford Advanced Learners, Dictionary of Current English, Oxford University Press

[9] James T.G (2007) "Problem of Religion" The way Out for Peace and Development in Nigeria" In Peace, Security and National Development

[10] Khah, Z (1993) "The Fundamental of Peace" Religion and Peace Proceeding of the Kyolo Conference and Religion and Peace, New Delhi Kirk Patrick S.M Ediburgh, WOR Chambers Ltd

[11] Mattew, and Ladan, J.B (2004) "In Search for Peace in Nigeria, The Educational Implication" Gidan Waya Journal of Education, Vol, 21001 and 2, P, 0-226

[12] Olupona, J.K (1992): Religion and Peace in Multi-faith Nigeria (Ile-Ife, Obafemi Awolowo University.

[13] Ogege, S.O (2009) "Violent Conflict in Nigeria Patters and Resolution Options" In Journal of Social Psychology Practice, International Perspective, $\mathrm{Vol}, 1$. No.1\&2 
[14] Ogidi, D.P (2004) "Youths and Peace Building for Sustainable Development in Nigeria" In Godwin, A, et. al (Eds) Education for Sustainable Development in Nigeria, Vol, 1, Peak Press, Minna, pp 102-121

[15] Olayode, K. (2006) "Globalization, Sustainable Development and State Capacity in Africa" In Nigeria Journal of International Affairs, Vol 32, No 1, Lagos, N.1.1.A

[16] Oriade T, Et al (2009) "Blood bath in North" The News Vol, 33 No. 05 Pp, 27

[17] Orude, P. (2009): Bloody “Talibans” Saturday Sun August, 1 Vol.6 Nol.341.pg 41.

[18] Otite, O (2001): Sociology Dimensions of Researching Ethnicity and Ethnic Conflict in Nigeria , jos ,pp-25-40

[19] The New Encyclopedia Britain Micropaedia Knowledge in Depth (1480) Vol,16, Encyclopedia Britannica Inc .U.S.A

[20] The World Book Encyclopedia International (1996) Vol, 15, A Scott Fetzer Company, London.

[21] World Developing Report (2003) in Afinota L.A (2009) "The Niger Delta Crisis in Nigeria, Issue, Challenge and Prosperities" Journal of Sociology Psychology and Anthropology in Practice, Vol, No. 11/2 